\title{
An Educational Design Process for Different Capstone Classes
}

\author{
Mohamed El-Sayed \\ Department of Mechanical Engineering \\ Kettering University, Flint, MI 48504
}

\begin{abstract}
Capstone design classes are usually structured around teamwork and an open-ended design project. For Mechanical Engineering Departments with several specialties, several capstone classes are usually offered. To achieve the program learning objectives and outcomes across the different specialty, the need for a common educational capstone design process arises.

In this paper a common educational capstone design process that parallels that of leading corporations and can be followed across different capstone classes with application to machine design and automotive capstone classes is presented. The developed process fosters creativity, develops students' communication skills and provides a logical product realization engineering/management experience.
\end{abstract}

The educational design process starts with team building and brainstorming focusing on creativity as right brain activity. From the brainstorming list of projects one is selected based on creativity, effort and timing. Each team proceeds to develop a written and oral proposal containing product history, state of the art, Bill of Product, development and simulation methodology, project management/impacts and cost estimates. The Bill of Product represents the set of product attributes from which design criteria and engineering targets are derived.

The proposal and project management chart become the road map for tracking until completion. Design construction, analysis and simulation, safety, ethics, social and political implications to design decisions are lectured on until the Bill of Materials is populated for the progress report and presentation. Students are then lectured on design synthesis/validation, quality, manufacturability and variations until the Bill of Process is developed for the final report and presentation. 


\section{Introduction}

Capstone design classes for Mechanical Engineering students usually entail one open-ended design project. For Mechanical Engineering Departments with several specialties, such as the case at Kettering University, several capstone classes are usually offered. To achieve the program learning objectives and outcomes across the different specialty, the need for a common educational capstone design process arises.

A common educational capstone design process should address several needs. First, it should provide student with a comprehensive and realistic product realization engineering/management experience that represents real life in different engineering settings. Second, it should meet and exceed the global learning educational objectives for any capstone level design class. Finally, it should be modular and applicable to any capstone class independent of the design project type.

In this paper a common educational capstone design process that parallels that of leading corporations and can be followed across different capstone classes with application to machine design and automotive capstone classes is presented. The developed process fosters creativity, develops students' communication skills and provides a logical product realization engineering/management experience. Another advantage of the developed process is the ability to fit different length of school terms. Due to the co-op program at Kettering University the class term is eleven weeks. The developed process was fitted to the eleven weeks timing with two 120 minutes sessions per week.

\section{Process Educational Objectives}

To provide students with a comprehensive and realistic product realization engineering/management experience and be applicable to any capstone class, the following are the main preset educational objectives of the developed process:

\section{Objective 1: Creative thinking in design}

1.1 Students will be able to brainstorm and think creatively to achieve alternate design solutions.

Objective 2: Teamwork and communication skills

2.1 Students will be able to form teams and work effectively with others to achieve design goals.

2.2 Student will be able to present their ideas, plans and design alternatives in written and oral formats.

Objective 3: Project planning and management

"Proceedings of the 2004 American Society for Engineering Education Annual Conference \& Exposition Copyright (C) 2004, American Society for Engineering Education” 
3.1 Student will be able to use project's planning tools to plan tasks, timing and coordinate design activities.

Objective 4: Identify product attributes and design criteria.

4.1 Student will be able to use systematic design process thinking to analyze the conceptualized product attributes and transfer these attributes to design criteria and engineering targets

Objective 5: Product simulation and synthesis

5.1 Student will be able to apply their education to simulate the conceptualized product in the intended environment and synthesize to achieve targets and attributes.

\section{Prerequisites and skills:}

For the effective and successful implementation of the process in capstone classes, students should have the following, standing, skills, and prerequisites:

1. Senior Standing

2. CAD Skills

3. Analysis and simulation Skills

4. Design of Mechanical Elements

5. Basic computer skills

\section{Educational Design Process Flow}

Due to the co-op program at Kettering University the class term is eleven weeks. The developed process was fitted to the eleven weeks timing, with two 120 minutes sessions per week. Meeting the requirement of eleven week term demonstrates the ability of the developed process to fit lengthier school terms easily.

Starting with week one lectures on team dynamics and team formations criteria are conducted. Students select their teams based on the laid out criteria, with the following two main objectives:

1. Ability to work together

2. Technically complement each other

After forming teams students are then lectured on brain storming skills and creativity as right brain activity on individual and team level. The key for successful brain storming sessions is to suspend judgment and allow creative ideas to flow. By practicing brain storming students prepare a list of potential projects. From the list of projects one is selected based on the following criteria:

1. Originality and creativity

2. Enough work for all the team members

3. Ability to deliver desired results within class time frame.

"Proceedings of the 2004 American Society for Engineering Education Annual Conference \& Exposition Copyright (C) 2004, American Society for Engineering Education" 
During the second and third weeks students are lectured on the design process, project selection and planning, bill of product, product attributes, project management, proposal writing and presentation. The lecturing continues on relating the product attributes to design criteria, engineering targets. This culminates into the proposal development and delivery at the end of the third week of class.

The proposal developed by each team with the project management chart becomes the road map for the team to the end of term. Design construction, design development and simulation methodology, analytical simulation, design synthesis and optimization, safety, ethics, social and political implications to design decisions are lectured on during week four to week seven. The design construction, analysis and simulation work are developed during these four weeks. The Bill of Materials is populated during the four weeks for the progress report at the end of week seven.

From week seven to eleven student are lectured on Manufacturability, Bill of process development, variation, quality, reliability, product life cycle, and design validation. During this period the Bill of Process is developed, populated and design project is finalized. These activities culminate into the final report and presentation during the eleventh week.

The educational design process flow diagram is presented in Figure 1, and the main topics covered for each class period are presented in Table 1. The duration and coverage depth for each topic can be expanded for school terms with more than eleven weeks.

As shown by the developed capstone educational process flow diagram, the process is tailored around an industrial based design process. The educational process starts by covering an important but absent aspect of engineering education. This aspect is the relationship between engineering requirements or targets and the desired final product and its attributes. The flow down of attributes defined in the end user domain to design criteria defined in the engineering domain from which a set of targets are derived for analysis and simulation is the key for any successful product design and educational efforts.

After identifying the target for each attribute and ranking these targets according to preset priority for each attribute the design construction, simulation, synthesis and optimization can be performed. The success in this stage hinges on the ability to perform representative virtual or physical simulations and choose the proper design alternative to achieve the desired attributes within the priority structure. 


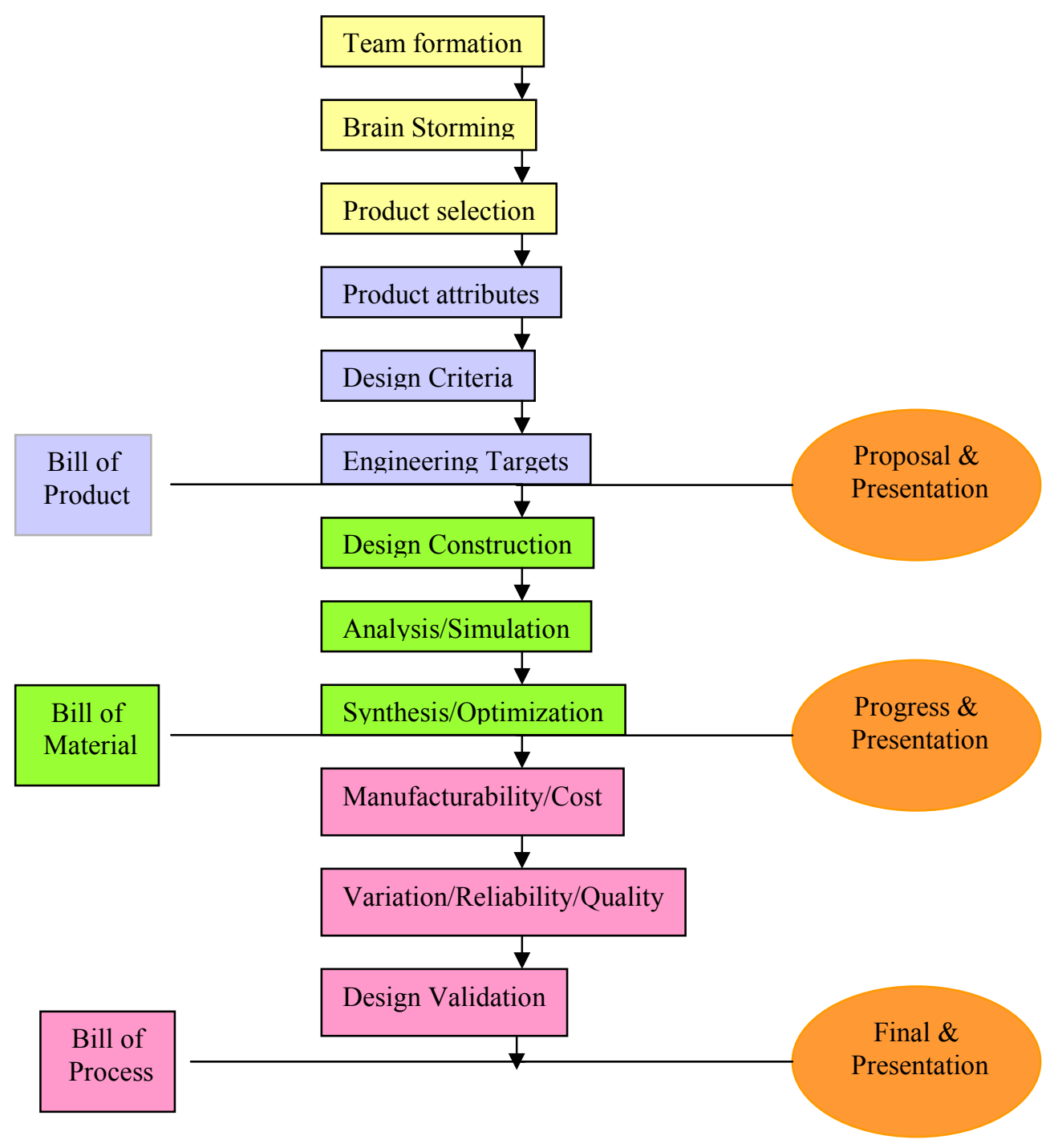

Figure 1: Educational Design Process Flow Diagram

"Proceedings of the 2004 American Society for Engineering Education Annual Conference \& Exposition Copyright @ 2004, American Society for Engineering Education" 


\title{
Topics covered:
}

\author{
Week Topic \\ $1 \quad$ Team formation and working in teams \\ Brainstorming and creativity in design \\ 2 The engineering design process and Project selection \\ Project planning and Proposal writing \\ 3 Product attributes (bill of product), design criteria and engineering targets \\ Written proposal and in class presentations delivered \\ 4 Project management and bill of materials development \\ Design construction \\ $5 \quad$ Product virtual and physical Simulations/Analysis \\ Design analysis, synthesis and optimization \\ 6 Progress reports and presentation preparation \\ Alternative Designs selection \\ 7 Ethical, social and political implications of engineering design decisions \\ Progress reports and in class presentations delivered \\ $8 \quad$ Manufacturability and Bill of process development \\ Cost analysis and minimization \\ $9 \quad$ Product and manufacturing variations \\ Product quality and reliability \\ 10 Product life cycle, maintainability and serviceability considerations \\ Final reports and presentation preparation \\ 11 Design validation \\ Final reports and in class presentations delivered
}

Table 1: Eleven weeks-Two sessions of 120 minutes per week

\section{Process Application Examples}

The developed process has been successfully used for machine design capstone and automotive design capstone classes over several years at Kettering University. It provided a structured approach to project management and product design while allowing student to find creative solutions to their design problems. It allowed students to use off the shelve technologies to focus their efforts on the needed component and simulations to achieve the desired product attributes. In the following selected deliverables of two capstone projects are presented to demonstrate the application of the process in a machine design capstone class and automotive design capstone class.

"Proceedings of the 2004 American Society for Engineering Education Annual Conference \& Exposition Copyright @ 2004, American Society for Engineering Education" 


\section{Machine Design Capstone Example:}

The Ultimate ZX2002 Billiards Gaming Systems

\section{Proposed Project/Objectives}

- Automated Precision Racking System

- Automated Cleaning System

- Digital Interface w/ Multiple Game play Modes

- Automatic Cue Chalking System

- Ball Position System (BPS)

- Laser Technology for Shot Advice

- Multiple Lighting Arrays

\section{Attributes}

- Quality

- Top-Notch Performance

- Aesthetic Visual Appearance

- Durable

- Intelligent

\section{Design Criteria}

- $\quad 50$ " x 100" Playing Surface

- Precision Machined Slate

- Regulation Felt

- $\quad$ Oak Frame Utilizing Dovetail Joints

- $\quad$ BPS System w/ Top Electronic Components

- Max. Weight: 1000 lbs.

- Min. Lifetime: 25 years

\section{Technical Requirements}

- Structure: $27,000 \mathrm{lbs}$ at 0.03 " Deflection

- Slate: 0.01" Flatness

- Canvas: Proper Weave and Weight

- $\quad$ BPS: Location to within 0.01" Accuracy

- Vacuum System: Capable of Cleaning all Angles of Playing Surface

"Proceedings of the 2004 American Society for Engineering Education Annual Conference \& Exposition Copyright @ 2004, American Society for Engineering Education” 


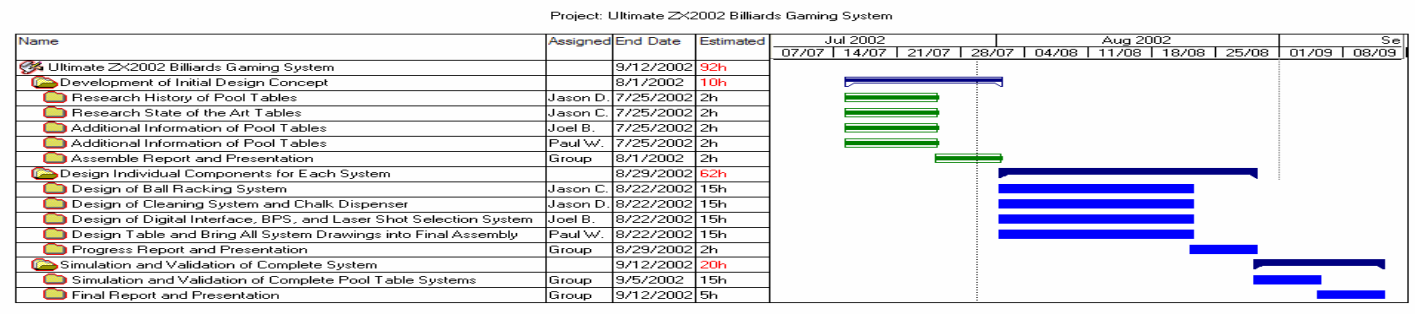

Printed using IPSO Workbench

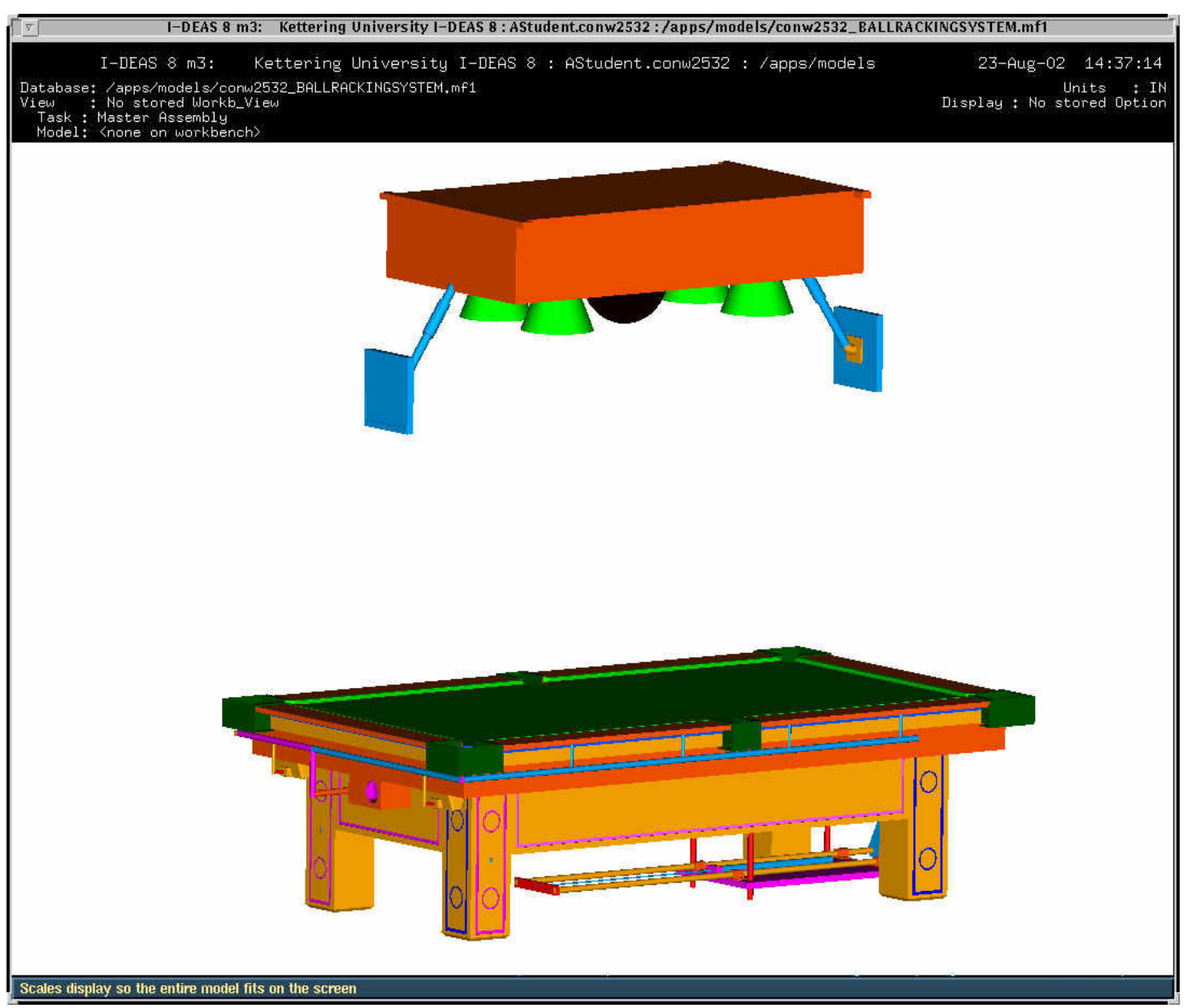

The Ultimate ZX2002 Billiards Gaming Systems

"Proceedings of the 2004 American Society for Engineering Education Annual Conference \& Exposition Copyright @ 2004, American Society for Engineering Education" 


\section{Automotive Design Capstone Example:}

\section{$\underline{\text { Luxury Executive - 'LEX' }}$}

\section{ATTRIBUTES}

The attributes intended to appeal to the consumer are listed below:

- Comfortable and quite ride.

- Easy and economical to maintain and operate.

- Powerful and responsive feel.

- Convertible top.

- Good gas mileage.

- Comfortable, user-friendly interior.

\section{DESIGN CRITERIA}

- Comfortable and quite ride = Rigid body with low noise, vibration, and harshness.

- Easy and economical to maintain and operate = Oil change intervals over the average 4,000 miles and the first scheduled tune-up well into the life of the car.

- $\quad$ Powerful and responsive feel = High output engine with good skid pad performance.

- Convertible top = Retractable hardtop.

- $\quad$ Good gas mileage $=$ High tech engine and transmission.

- Comfortable, user-friendly interior = Ergonomics.

\section{ENGINEERING TARGETS}

- $\quad$ Rigid body with low noise, vibration, and harshness = Built on Lincoln Town Car Cartier L Chassis with body on frame design

- Oil change intervals over the average 3,000 miles and the first scheduled tune-up well into the life of the car = Oil change intervals at 4,000 miles and the first scheduled tune-up not until 100,000 miles.

- High output engine with good skid pad performance $=4.8 \mathrm{~L} 270$ horsepower engine and 0.80 g's on the skid pad.

- Retractable hard top = Less exterior noise while still having a convertible

- High tech engine and transmission = "Displacement on Demand" engine and Six-Speed Automatic Transmission.

- Ergonomic interior = Gauges within easy view of the driver and the controls are in easy reach. Comfortable and adjustable seating to fit the passengers. 
BILL OF MATERIAL

\begin{tabular}{|c|c|c|c|c|c|c|c|c|}
\hline \multirow{2}{*}{ Qty' } & \multirow{2}{*}{ Subsystem } & \multirow{2}{*}{ Part Number } & \multirow{2}{*}{ Design Criteria } & \multirow{2}{*}{ Engineering Targets } & \multirow{2}{*}{ Source } & \multirow{2}{*}{ Simulation } & \multirow{2}{*}{ Cost } & Status \\
\hline & & & & & & & & Targets \\
\hline \multicolumn{9}{|l|}{ Body } \\
\hline 2 & Front Door & B-0001 & \multirow{22}{*}{$\begin{array}{l}\text { Stiff Body with } \\
\text { Excellent Saftey } \\
\text { Ratings }\end{array}$} & \multirow{22}{*}{$\begin{array}{l}\text { Coefficient of Drag } \\
\text { Less Than } 0.35 \text {. }\end{array}$} & Lincoln OEM & \multirow{22}{*}{ Clay Model } & 200 & \multirow{23}{*}{ Completed } \\
\hline 2 & Rear Suicide Doors & B-0002 & & & Lincoln OEM & & 200 & \\
\hline 2 & Front Fenders & B-0003 & & & Lincoln OEM & & 250 & \\
\hline 2 & Rear Quarter Panels & B-0004 & & & Lincoln OEM & & 250 & \\
\hline 1 & Retractable Hardtop & B-0005 & & & Lincoln OEM & & 1250 & \\
\hline 2 & Rocker Panels & B-0006 & & & Lincoln OEM & & 75 & \\
\hline 1 & Hood & B-0007 & & & Lincoln OEM & & 400 & \\
\hline 1 & Deck Lid & B- -0008 & & & Lincoln OEM & & 350 & \\
\hline 2 & Headlights & B-0009 & & & Lincoln OEM & & 100 & \\
\hline 2 & Tail Lights & B-0010 & & & Lincoln OEM & & 100 & \\
\hline 1 & Grill & B-0011 & & & Lincoln OEM & & 300 & \\
\hline 2 & Front Fascia & B-0012 & & & Lincoln OEM & & 300 & \\
\hline 2 & Rear Fascia & B-0013 & & & Lincoln OEM & & 300 & \\
\hline 1 & Windshield & B-0014 & & & Lincoln OEM & & 500 & \\
\hline 1 & Rear Window & B-0015 & & & Lincoln OEM & & 300 & \\
\hline 2 & Front Door Windows & B-0016 & & & Lincoln OEM & & 200 & \\
\hline 2 & Rear Door Windows & B-0017 & & & Lincoln OEM & & 150 & \\
\hline 2 & Front Wheel well Inserts & B-0018 & & & Lincoln OEM & & 65 & \\
\hline 2 & Rear Wheel Well Inserts & B-0019 & & & Lincoln OEM & & 65 & \\
\hline 1 & Floor Pan & B- -0020 & & & Lincoln OEM & & 1000 & \\
\hline 1 & Firewall & B-0021 & & & Lincoln OEM & & 750 & \\
\hline 1 & Trunk Pan & B-0022 & & & Lincoln OEM & & 500 & \\
\hline 1 & Body Assembly & BS-0001 & & & & tal Cost for Body & 7605 & \\
\hline \multicolumn{9}{|c|}{ Engine } \\
\hline \begin{tabular}{|l|}
1 \\
\end{tabular} & 4807 CC Vortec V8 & E-0001 & \multirow{5}{*}{$\begin{array}{l}\text { Displacement on } \\
\text { Demand, Good Fuel } \\
\text { Economy }\end{array}$} & \multirow{5}{*}{$\begin{array}{l}\text { Engine can run as a } \\
\text { V8 or a V4. } 20 / 30 \\
\text { mpg }\end{array}$} & GM & \multirow{5}{*}{ Advisor } & 2250 & \\
\hline 1 & Transmission & E-0002 & & & Ford OEM & & 1500 & \\
\hline 1 & Rear Differential & E-0003 & & & Ford OEM & & 750 & Comnleted \\
\hline 1 & Drive Shaft & E-0004 & & & Ford OEM & & 100 & Completed \\
\hline 1 & Electronics & ES-0002 & & & Ford OEM & & 1000 & \\
\hline 1 & Powertrain Assembly & ES-0001 & & & & Cost for Engine & 5600 & \\
\hline Chassi & & & & & & & & \\
\hline 1 & Frame & C-0001 & & Over 0.8 Lateral q's. & Ford & & 1000 & \\
\hline 2 & Front Springs & C-0002 & & & Eibach & & 250 & \\
\hline 2 & Rear Springs & C-0003 & Good handling for a & & Eibach & & 250 & \\
\hline 1 & Front Suspension & C- -0004 & large car yet still has a & Less tnen 4.5 pitch & Ford & CarSIM & 500 & \\
\hline 1 & Rear Suspension & C-0005 & smooth ride & and less then $3^{\circ}$ roll at & Ford & & 500 & Completed \\
\hline 4 & Wheels & C-0006 & & & Center Line & & 175 & \\
\hline 4 & Tires & C- 0007 & & & GoodYear & & 110 & \\
\hline 1 & Chassis Assembly & CS-0001 & & & & Cost for Chassis & 2785 & \\
\hline Interior & & & & & & & & \\
\hline 1 & Driver Seat & $1-0001$ & & & Jaguar OEM & & 800 & \\
\hline 1 & Passanger Seat & $1-0002$ & & & Jaguar OEM & & 800 & \\
\hline 1 & Split Rear Bench & $1-0003$ & & Leather \& Wood Trim, & Jaguar OEM & & 1200 & \\
\hline 1 & Radio & $1-0004$ & Refined, Polished, \& & 10 Speakers with a & Alpine & & & \\
\hline 1 & Nav System/DVD & $1-0005$ & Comfortable. Great & 320 Watt Amp. 8-way & Alpine & Paint Shop Pro & 3000 & \\
\hline 10 & Speakers & $1-0006$ & Sound. Automatic & Power adjustable & Alpine & & & Completed \\
\hline 3 & Mini Screens & $1-0007$ & Controls & seats & ProScan & & 1200 & \\
\hline $\mathrm{N} / \mathrm{A}$ & Wood Trim & $1-0008$ & & & Jaguar OEM & & 300 & \\
\hline 1 & Computer & $1-0009$ & & & Dell & & 1500 & \\
\hline 1 & Interior Assembly & IS-0001 & & & & Cost for Interior & 8800 & \\
\hline
\end{tabular}

"Proceedings of the 2004 American Society for Engineering Education Annual Conference \& Exposition Copyright (c) 2004, American Society for Engineering Education" 


\section{SIMULATION \& METHODOLOGY}

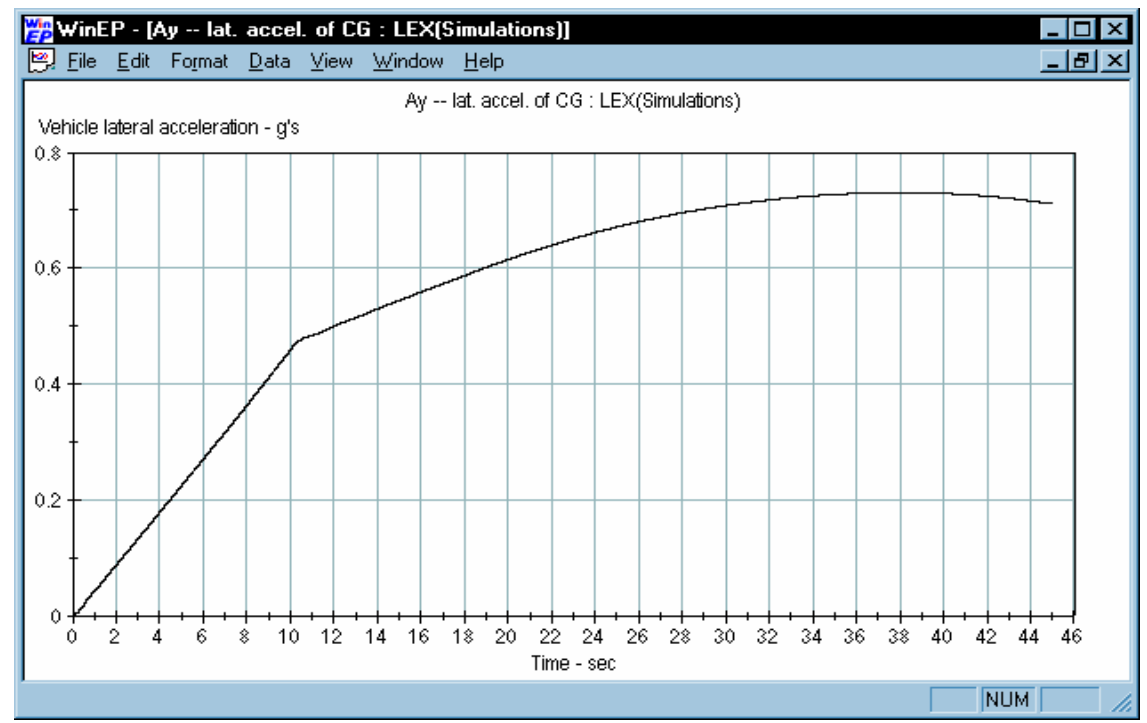

\section{Lateral Acceleration "LEX"}

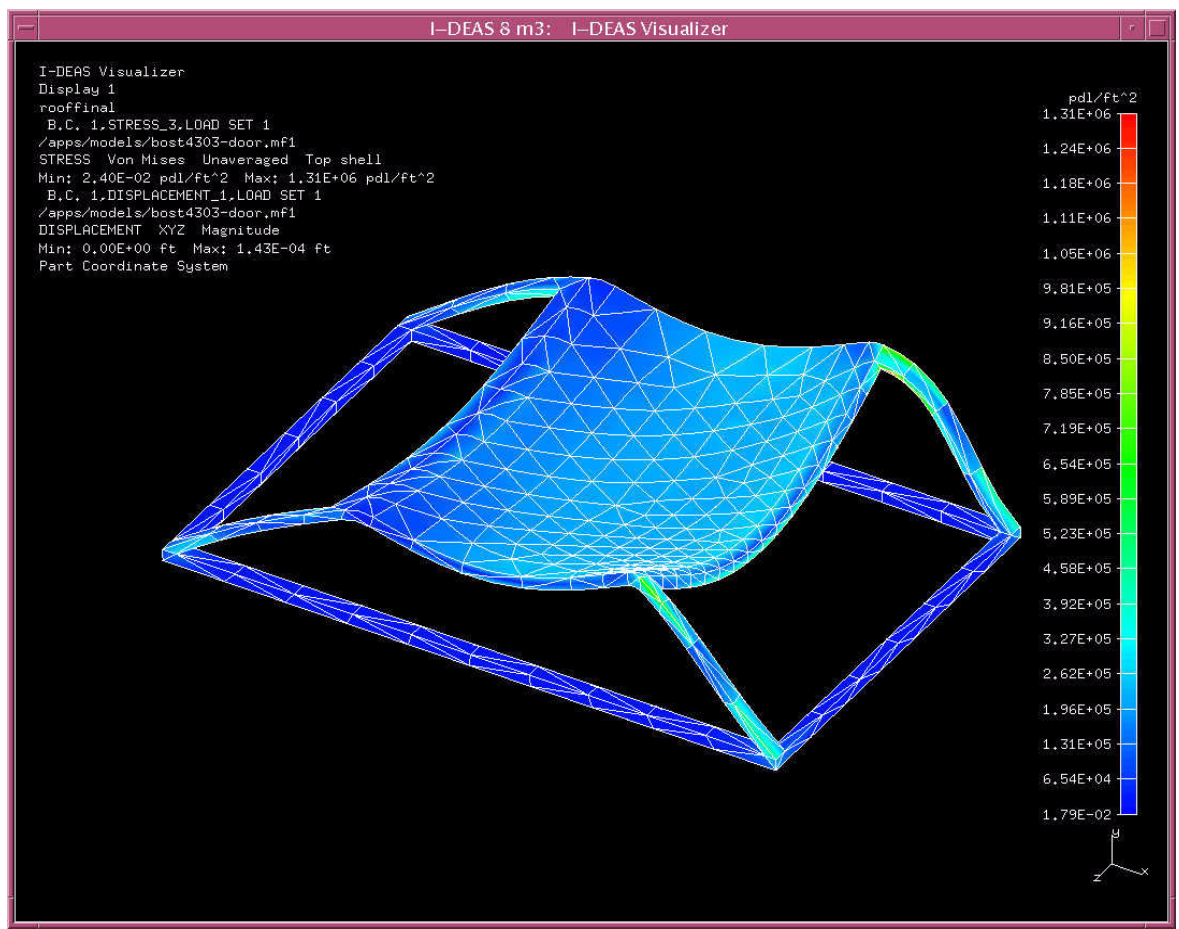

Carbon Fiber Roof Crush FEA

"Proceedings of the 2004 American Society for Engineering Education Annual Conference \& Exposition Copyright @ 2004, American Society for Engineering Education" 


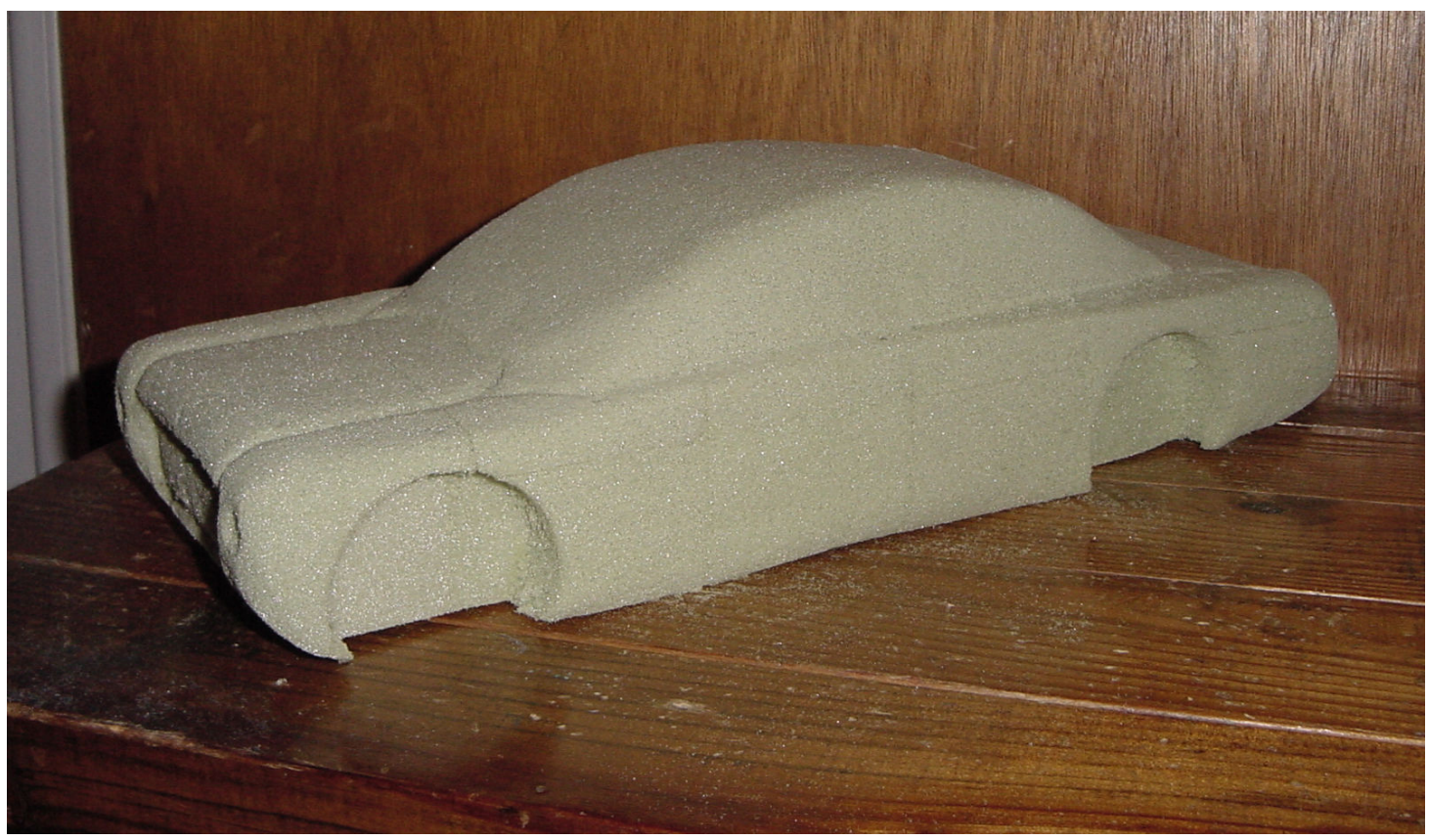

Foam Model of the LEX Front View

\section{ENGINE ANALYSIS}

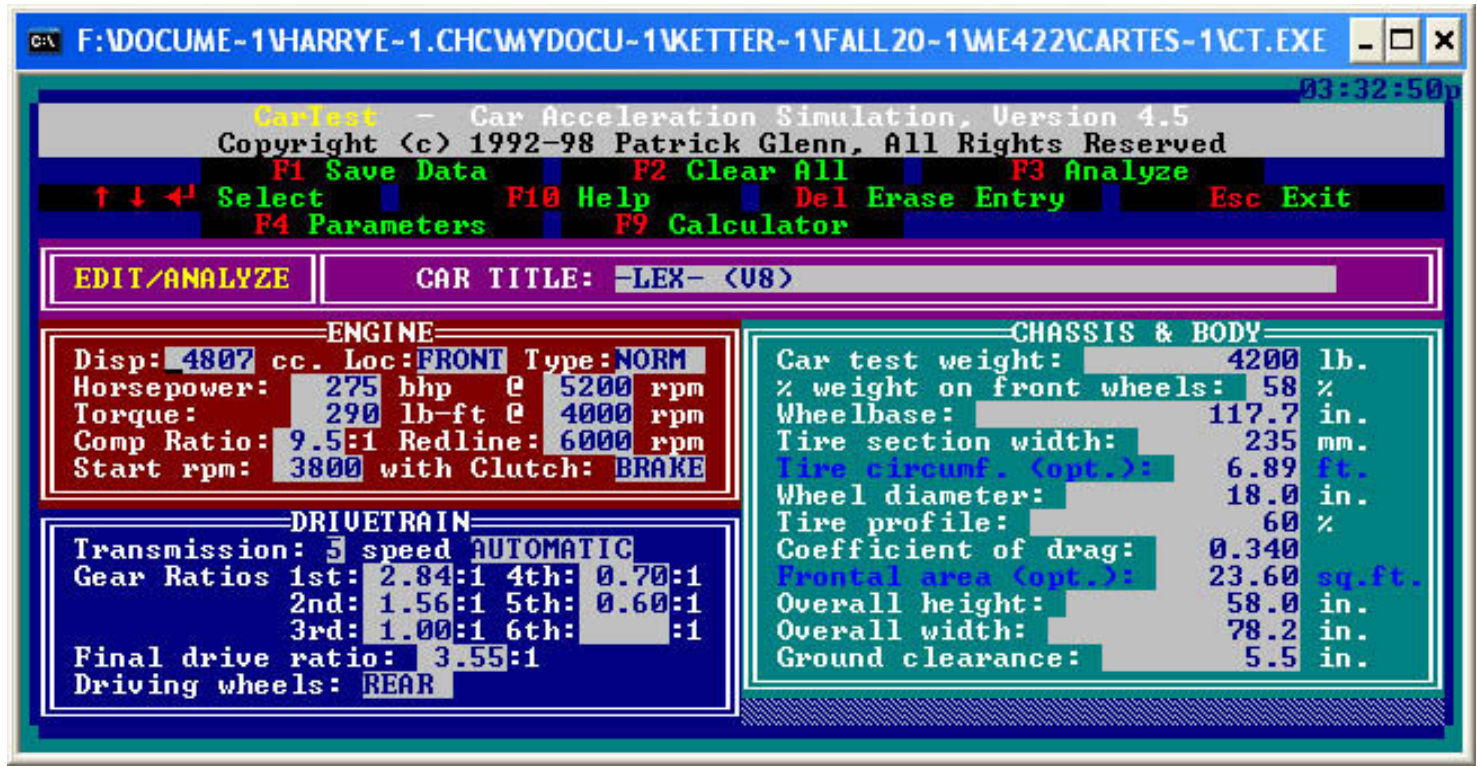

V8 Engine Model

"Proceedings of the 2004 American Society for Engineering Education Annual Conference \& Exposition Copyright @ 2004, American Society for Engineering Education" 


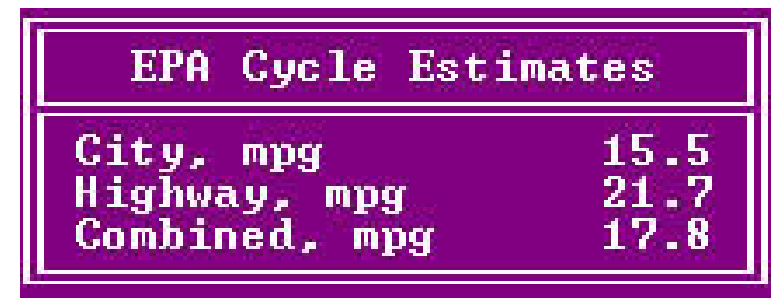

V8 Fuel Economy

\section{BILL OF PROCESS}

\begin{tabular}{|c|c|c|c|c|c|c|c|}
\hline Subsytem & Part \# & Source & $\begin{array}{l}\text { Manufacturing } \\
\text { Process }\end{array}$ & Finish & Assembley Sequence & Fastner & Fits \& Tolerene \\
\hline \multicolumn{8}{|l|}{ Bodv } \\
\hline Front Door & B-0001 & Lincoln OEM & \multirow{8}{*}{$\begin{array}{l}\text { Sheet Metal } \\
\text { Stamping }\end{array}$} & \multirow{8}{*}{ Paint \& Clear } & \multirow{22}{*}{$\begin{array}{l}\text { 1. Mount Floorpan to Frame } \\
\text { 2. Install Firewall } \\
\text { 3. Mount Rocker Panels } \\
\text { 4. Mount Fenders and Quarters } \\
\text { 5. Install Lights into Fascias } \\
\text { 6. Install Front and Rear Fascias } \\
\text { 7. Install Trunk Pan } \\
\text { 8. Install Doors } \\
\text { 9. Install Hood and Deck Lid } \\
\text { 10. Install Glass and Grill }\end{array}$} & \multirow{22}{*}{$\begin{array}{l}\text { Bolts and } \\
\text { Welds }\end{array}$} & \multirow{22}{*}{$\begin{array}{l}\text { Standard Ford } \\
\text { tolerances for } \\
\text { automotive } \\
\text { bodies }\end{array}$} \\
\hline Rear Suicide Doors & B-0002 & Lincoln OEM & & & & & \\
\hline Front Fenders & B-0003 & Lincoln OEM & & & & & \\
\hline Rear Quarter Panels & B-0004 & Lincoln OEM & & & & & \\
\hline Retractable Hardtop & B- -0005 & Lincoln OEM & & & & & \\
\hline Rocker Panels & B-0006 & Lincoln OEM & & & & & \\
\hline Hood & B-0007 & Lincoln OEM & & & & & \\
\hline Deck Lid & B-0008 & Lincoln OEM & & & & & \\
\hline Headlights & B-0009 & Lincoln OEM & \multirow{2}{*}{\multicolumn{2}{|c|}{ Standard Process for Lights }} & & & \\
\hline Tail Lights & B-0010 & Lincoln OEM & & & & & \\
\hline Grill & B-0011 & Lincoln OEM & & Chrome & & & \\
\hline Front Fascia & B-0012 & Lincoln OEM & \multirow{2}{*}{$\begin{array}{l}\text { Sheet metal } \\
\text { stamping }\end{array}$} & \multirow{2}{*}{ Paint \& Clear } & & & \\
\hline Rear Fascia & B-0013 & Lincoln OEM & & & & & \\
\hline Windshield & B-0014 & Lincoln OEM & \multirow{4}{*}{ Obtain from Vendor } & \multirow{4}{*}{$\mathrm{N} / \mathrm{A}$} & & & \\
\hline Rear Window & B-0015 & Lincoln OEM & & & & & \\
\hline Front Door Windows & B-0016 & Lincoln OEM & & & & & \\
\hline Rear Door Windows & B-0017 & Lincoln OEM & & & & & \\
\hline Front Wheel well Inserts & B-0018 & Lincoln OEM & \multirow{5}{*}{$\begin{array}{l}\text { Sheet Metal } \\
\text { Stamping }\end{array}$} & \multirow{4}{*}{ Rust Protection } & & & \\
\hline Rear Wheel Well Inserts & B-0019 & Lincoln OEM & & & & & \\
\hline Floor Pan & B-0020 & Lincoln OEM & & & & & \\
\hline Firewall & B-0021 & Lincoln OEM & & & & & \\
\hline Trunk Pan & B-0022 & Lincoln OEM & & Paint \& Clear & & & \\
\hline \multicolumn{8}{|l|}{ Enqine } \\
\hline 4807 CC Vortec V8 & E-0001 & GM & \multicolumn{5}{|c|}{ Done by GM } \\
\hline Transmission & $\mathrm{E}-0002$ & Ford OEM & \multirow{4}{*}{\multicolumn{5}{|c|}{$\begin{array}{l}\text { Manufactured and assembled same as Lincoln Towncar Powertrain only replace standard 4.6L engine with part } \\
\text { number E-0001 }\end{array}$}} \\
\hline Rear Differential & E-0003 & Ford OEM & & & & & \\
\hline Drive Shaft & E-0004 & Ford OEM & & & & & \\
\hline Electronics & ES-0002 & Ford OEM & & & & & \\
\hline \multicolumn{8}{|l|}{ Chassis } \\
\hline Frame & C-0001 & Ford OEM & \multirow{7}{*}{\multicolumn{5}{|c|}{$\begin{array}{c}\text { Manufactured and assembled same as Linconl Towncar Chassis only replace standard springs with part } \\
\text { numbers C-0002 and C-0003. Replace standard tires with part number C-0007. Replace standard wheels with } \\
\text { part numbers C-0006 }\end{array}$}} \\
\hline Front Springs & C-0002 & Eibach & & & & & \\
\hline Rear Springs & $\mathrm{C}-0003$ & Eibach & & & & & \\
\hline Front Suspension & C-0004 & Ford OEM & & & & & \\
\hline Rear Suspension & C-0005 & Ford OEM & & & & & \\
\hline Wheels & C-0006 & Center Line & & & & & \\
\hline Tires & C- 0007 & Goodyear & & & & & \\
\hline \multicolumn{8}{|l|}{ Interior } \\
\hline Driver Seat & I-0001 & Jaguar OEM & \multirow{9}{*}{\multicolumn{2}{|c|}{ Obtain from Vendor }} & \multirow{9}{*}{$\begin{array}{l}\text { 1. Carpeting } \\
\text { 2. Dash } \\
\text { 3. Seats and Options }\end{array}$} & & \\
\hline Passenger Seat & $1-0002$ & Jaguar OEM & & & & & \\
\hline Split Rear Bench & $1-0003$ & Jaguar OEM & & & & & \\
\hline Radio & I-0004 & Alpine & & & & & Jinceln \\
\hline Nav System/DVD & $1-0005$ & Alpine & & & & Clips \& Bolts & tolerances for \\
\hline Speakers & I-0006 & Alpine & & & & & tolerances for \\
\hline Mini Screens & $1-0007$ & ProScan & & & & & Interiors \\
\hline Wood Trim & $1-0008$ & Jaguar OEM & & & & & \\
\hline Computer & 1-0009 & Dell & & & & & \\
\hline
\end{tabular}

"Proceedings of the 2004 American Society for Engineering Education Annual Conference \& Exposition Copyright @ 2004, American Society for Engineering Education" 


\section{Conclusion}

The educational design process presented covers several capstone design fundamental topics. These topics include: the engineering design process, teamwork, brainstorming, conceptual designs, proposal writing, project planning, project management, ethics, product attributes, design criteria, engineering targets, physical simulation, virtual simulation, analysis techniques, design synthesis, alternative designs, bill of materials, bill of process, manufacturability, product variations, product quality, design reports and presentations.

Besides developing students' engineering and communication skills the presented design process fosters creativity, the main educational objective in capstone design, and logical product realization engineering and project management skills. From the level of creativity and quality of the resulting capstone design projects and students' feed back it seems that the process is successful in meeting and exceeding its educational objectives. The process provides a road map for achieving the desired product attributes while allowing students to think freely and creatively out of the box. It also provided design and project management experience, in teamwork setting, based on real life industrial practices of leading corporations.

\section{References}

1. ATILA, E., and JONES, J., “ The Engineering Design Process,” John Wiley \& Sons, New York, 1993.

2. CROSS, N., "Engineering Design Methods," John Wiley \& Sons, New York, 1989.

3. PUGH, S., "Total Design,” Adison-Wesley Publishing Company, Wokingham, England, 1991.

4. PAHI, G., and BETTZ, W., "Engineering Design: A Systematic Approach," The Design Council, London, England, 1988.

\section{Biographical Information}

MOHAMED El-SAYED, Ph. D. is a professor of Mechanical Engineering at Kettering University and has been teaching at the undergraduate and graduate level for over 25 years. He teaches Machine Design, Automotive Design, Design Optimization, Mechanics, and Nonlinear Finite Element analysis. He is a consultant for several engineering corporations and has over fifty research papers on multidisciplinary Design optimization.

"Proceedings of the 2004 American Society for Engineering Education Annual Conference \& Exposition Copyright @ 2004, American Society for Engineering Education" 